\title{
Honoré de Balzac, Eugenia Grandet
}

\section{Marco Stupazzoni}

\section{Q OpenEdition}

\section{Journals}

\section{Edizione digitale}

URL: https://journals.openedition.org/studifrancesi/39627

DOI: 10.4000/studifrancesi.39627

ISSN: 2427-5856

\section{Editore}

Rosenberg \& Sellier

\section{Edizione cartacea}

Data di pubblicazione: 1 décembre 2004

Paginazione: 394

ISSN: 0039-2944

\section{Notizia bibliografica digitale}

Marco Stupazzoni, «Honoré de Balzac, Eugenia Grandet», Studi Francesi [Online], 143 (XLVIII | II) | 2004

online dal 30 novembre 2015, consultato il 19 mai 2021. URL: http://journals.openedition.org/

studifrancesi/39627 ; DOI: https://doi.org/10.4000/studifrancesi.39627

Questo documento è stato generato automaticamente il 19 mai 2021.

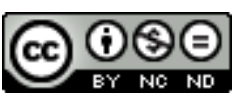

Studi Francesi è distribuita con Licenza Creative Commons Attribuzione - Non commerciale - Non opere derivate 4.0 Internazionale. 


\title{
Honoré de Balzac, Eugenia Grandet
}

\author{
Marco Stupazzoni
}

\section{NOTIZIA}

HONORÉ DE BALZAC, Eugenia Grandet, traduzione di Gabriella ALZATI, Milano, BUR, 2003

(«Superbur Classici», 266), pp. 201.

1 Segnaliamo la ristampa, nella collana dei "Superbur Classici" di Rizzoli, della traduzione italiana del capolavoro balzachiano curata, nel 1949, da Gabriella Alzati. Il romanzo è preceduto da una breve Nota introduttiva (pp. 5-6), in cui è presentato un sommario e alquanto superficiale profilo biografico-letterario dell'autore con alcuni brevi riferimenti all'opera in questione, la cui 'fabula', «storia in grigio d'un grigio destino di donna», secondo la definizione del Valeri (p. 6), si fonda sulla diretta osservazione della drammatica complessità del vero. 